\title{
Study of mural paintings by Fulvio Pennacchi in São Paulo City by mineralogical techniques
}

\author{
ELIANE A. DEL LAMA ${ }^{1}$, REGINA A. TIRELLO ${ }^{2,3}$, FÁBIO R.D. DE ANDRADE ${ }^{1}$ \\ and YUSHIRO KIHARA ${ }^{1}$ \\ ${ }^{1}$ Instituto de Geociências, Universidade de São Paulo, Rua do Lago, 562, 05508-080 São Paulo, SP, Brasil \\ ${ }^{2}$ Centro de Preservação Cultural, Universidade de São Paulo, Rua Major Diogo, 353, 01324-001 São Paulo, SP, Brasil \\ ${ }^{3}$ Faculdade de Engenharia Civil, Arquitetura e Urbanismo, Universidade de Campinas \\ Av. Albert Einstein, 951, 13083-852 Campinas, SP, Brasil \\ Manuscript received on December 6, 2007; accepted for publication on July 29, 2008, \\ presented by ALCIDES N. SIAL
}

\begin{abstract}
The present research deals with two mural paintings made in 1947 with the fresco technique by Fulvio Pennacchi in the Catholic Chapel of the Hospital das Clínicas (São Paulo City, Brazil), namely the Virgin Annunciation and the Supper at Emmaus. This study regards the materials and painting techniques used by the artist, based on historical research, on in situ observations and laboratory analytical techniques (stereomicroscopy, scanning electron microscopy with an energy dispersive spectrometer, X-ray diffractometry, electron microprobe, images obtained with UV-light), aiming to improve the methods of characterization of objects of our cultural heritage, and to enhance its preservation accordingly. The results lead to the identification of the plaster components and of distinct layers in the frescoes, besides further information on grain size, impurities and textures, composition of pigments, and features of deterioration, such as efflorescences. The degree of degradation of the murals painting was assessed by this way. Our data suggest that a single layer of plaster was used by Pennacchi, as a common mortar with fine- and medium-grained aggregates. Differences in texture were obtained by adding gypsum to the plaster.
\end{abstract}

Key words: efflorescence, frescoes, mineralogical analysis, Pennacchi, Chapel of the Hospital das Clínicas.

\section{INTRODUCTION}

Following the manifestations of modern architecture, artistical mural painting experienced a rebirth after 1930 in Brazil. Several known artists, such as Cândido Portinari, Sansom Flexor, Carlos Magano, Marcier, Jenner Augusto, Alfredo Volpi and Fulvio Pennacchi, produced large mural paintings in public and private buildings, using different pictorial techniques, including the traditional fresco. It is noteworthy that, although these artists did know the buon fresco technique, they modified and recreated it, trying to reach new aesthetical results.

Several mural paintings from that time are known

Correspondence to: Eliane A. Del Lama

E-mail: edellama@usp.br in Brazil, including works with different styles and techniques made by the so-called modernists.

Given its importance in the Brazilian mural art, Pennacchi's oeuvre has been extensively analysed (Bardi 1980, Pennacchi 2002, Pinacoteca 2006, A.R. Quedas, unpublished data, V.R.B. Wilhelm, unpublished data), but there is no study so far on his technique and on the materials he used. The aim of this paper is to identify, by means of analytical techniques, the plasters, the pigments and the procedures he used, particularly in the frescoes made in 1947 at the Catholic Chapel of the Hospital das Clínicas (São Paulo City, Brazil), opened for the public in 1944. This in-depth study of Pennacchi's mural paintings also aims to establish scientifical or 
technical criteria to assess the degree of decay, in order to give support for future restoration.

\section{THE ARTIST FULVIO PENNACCHI}

Fulvio Pennacchi was born in Tuscany, Italy, in 1905, and died in São Paulo, Brazil, in 1992. He came to Brazil in 1929 and settled in São Paulo. In the second half of the 1930's, Pennacchi integrated the Grupo Santa Helena, a group of Brazilian and immigrant painters, such as Rebolo, Aldo Bonadei, Alfredo Volpi, Clovis Graciano and others. They have also formed another group named Família Artistica Paulista. Both groups were associations of artists dedicated to the development of artistic techniques and their divulgation.

A fresco painting is done on wet plaster with pigments ground in water only. The fresco technique is based on the property of lime, together with sand, water and pigments, forming a stable and waterproof structure, which is a key feature of the buon fresco. Carbonation is an intrinsic process of fresco paintings, by which calcium carbonate is formed due the evaporation of water used as solvent of calcium hydroxide in the wet plaster and further combination with atmospheric carbon dioxide.

The mezzo fresco technique consists in painting after the partial solidification of the plaster. Pigments are mixed with lime and water in order to guarantee their penetration in the partially solidified plaster (Mayer 1982).

Pennacchi usually worked on canvases and in mural paintings with tempera and oil, and although fresco was not his field of expertise, he made his own experiments with it, while doing several sacred and profane mural paintings in São Paulo between 1930 and 1950. Pennacchi was one of the precursors of this technique in São Paulo City, as Bardi (1980) ascribed to him the first fresco made in São Paulo, in 1939, but Lourenço (1995) points out to an older one, made by Antonio Gomide in 1932.

Pennacchi made mural paintings in churches and public and private buildings, most of them in São Paulo City. The frescoes at the Church and Convent of Nossa Senhora da Paz (1942) are among his best works. Other murals are the Chapel of Vila São Francisco (1948), Banco Auxiliar de São Paulo (1954), Hotel Príncipe
(1954), Church of the Orfanato Cristóvão Colombo (1955), Liga das Senhoras Católicas (1957) and the Church of Nossa Senhora Auxiliadora (1959). Other frescoes outside São Paulo were made at the Toriba Hotel, Campos do Jordão, São Paulo State (1943), Cathedral of Uruguaiana, Rio Grande do Sul State (1945), and the Church of Ribeirão Pires, São Paulo State (1954).

Once his first works were concluded, Pennacchi was invited by Victor Brecheret to paint two frescoes in the Chapel of the Hospital das Clínicas, in which Brecheret had made a via crucis with bronze sculptures (M.C.C. André, unpublished data). In this way, in 1947 Pennacchi painted two biblical scenes behind the altar of that Chapel: Virgin Annunciation $(232 \times 265 \mathrm{~cm})$ and Supper at Emmaus $(237 \times 245 \mathrm{~cm})$ (Fig. 1). It should be stressed that these paintings were chosen for this study because of their state of authenticity, i.e. they were not substantially changed by restorations, thus they have their original materials preserved, which is a keypoint for the purposes of this research. The areas that were changed by restorations can be easily identified by disarmed eye and was confirmed under ultraviolet light.

\section{MATERIALS AND METHODS}

Previous to the laboratory analyses of the frescoes, an on site survey was made. The analyses were made in samples carefully collected, in order to avoid damages to the paintings. The steps of the study were:

1. Recognition of the object. It was based on historical research, field observations, preliminary photographic register and sketches, according to procedures described by Tirello (2001).

2. Investigation of the technique. The surface of the paintings was analyzed in terms of the stability of the pigments and mortars. Photographies were taken under normal, raking and ultraviolet light.

Images with ultraviolet light did reveal anomalies and characteristics of alteration in the frescoes not seen under normal visible light and were used to locate the best spots for microsampling.

3. Based on these preliminary observations, a few questions were made:

- Did a single plaster was used to smoothen the supporting wall, while different textures were 

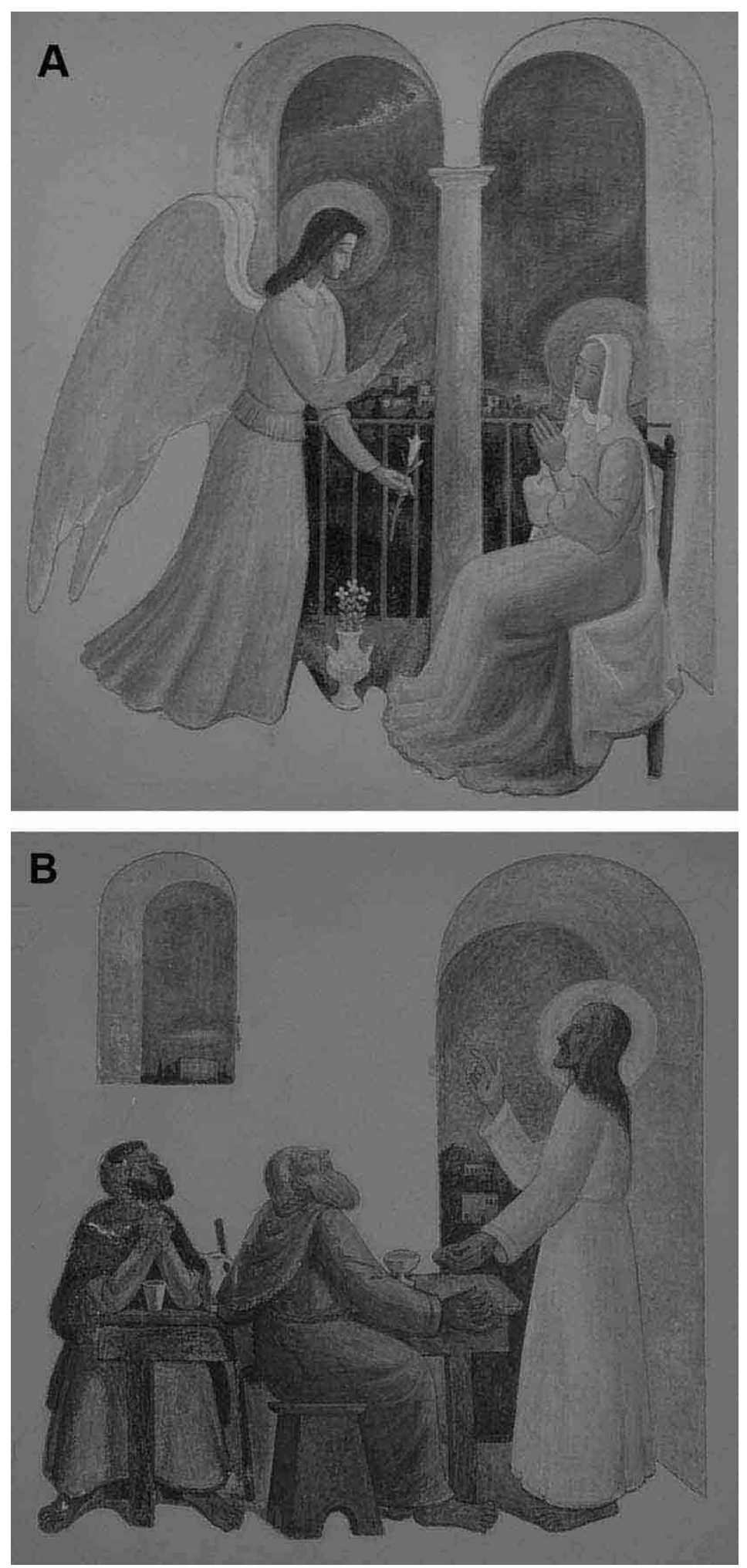

Fig. 1 - Virgin Annunciation (A) and Supper at Emmaus (B), frescoes painted by Pennacchi in 1947 in the Catholic Chapel of the Hospital das Clínicas (São Paulo City). 
produced by adding other materials to the lime and sand mortar?

- Was the used technique a buon fresco or $a$ mezzo fresco? Is the texturization of the painted surfaces changes due to the coloured material added or due to a mixed technique that uses both a fresco and a secco paintings, instead of granulometric changes in the raw material?

4. Mapping of textures. The differences observed in situ in the texture of the frescoes were classified in two generic types:

- Texture type 1: parts of pigmented mass, with a rather grainy aspect, in which the aggregates are visible. The colour pigments are spread out in the interstices of the grains, and do not form a proper layer, as it would be expected for a painting on a wet mortar. This texture suggests a thorough carbonation process.

- Texture type $2 a$ : coloured material with variable thickness that completely covers the underlying mortar. This suggests an a secco painting.

- Texture type $2 b$ : smooth surfaces covered by coloured mass or homogeneous paint, forming a fine texture layer. This also suggests an a secco technique.

5. Analytical procedures. The composition of the frescoes was studied, together with grain size measurements, textural aspects of the mineral raw materials, identification of smaller impurities, as well as characterization of deterioration and efflorescences. The frescoes were studied with stereomicroscopy, electron scanning microscopy, X-ray diffraction and electron microprobe.

In the literature, there are some references that suggest the efficiency of these techniques in the study of frescoes (Mora et al. 1984, Manzano et al. 2000, Pavía and Caro 2006, F. Droghini et al., unpublished data).

\section{EXECUTIVE TECHNIQUES OF FULVIO PENNACCHI}

Regarding the fresco technique in Pennacchi's works, A.R. Quedas (unpublished data) pointed out that he used a mixed technique called mezzo fresco, which was corroborated by our preliminary in situ observations, besides the buon fresco technique (Tirello and Del Lama 2006, Del Lama et al. 2007). In restricted parts of his murals, Pennacchi used the fresco with a secco technique finalization, indicated by a thin sample of the pictorial layer without any plaster below it.

Pennacchi mentioned in an interview to Maria Cecília F. Lourenço and Maria Cristina C.R. André, in September 29th, 1988 (M.C.C.R. André, unpublished data): "Most materials available here were imported
from abroad, including watercolours, etc. But
the materials used in fresco are simple pow-
der pigments, the same used to paint houses.
Since cobalt was not available here, red earths
worked out perfectly and lime was used for the
white colour. Very beautiful yellow earths do
exist."

"I used to mix water with lime, making a very white solution that afterwards was sieved in order to make it more porous. The sediment thus formed was then mixed with the pigment. Ancient artists used let the sediment to rest for a long time before using it."

A.R. Quedas (unpublished data) mentioned that Pennacchi used two layers in most of his mural paintings, where the outer layer was the support for the painting. However, this conclusion was not confirmed by stratigraphic analysis carried out by him. Also this statement could not be confirmed by us since the extraction of samples did not reach the supporting wall. Due this, our stratigraphic analysis have concentrated in the pictorial layer, including pigments and plaster. Our data suggest that Pennacchi used a single layer of plaster that was a common mortar with fine- and medium-grained aggregates. Differences in texture were obtained by adding other materials to the plaster of lime and sand.

Two quite distinct textures were observed in the mural paintings in the Hospital das Clínicas Chapel, as described in the previous section (Materials and Methods). In the areas where texture type 1 is present, aggregates and cementitious materials do not form a continuous layer, and the pigments are well embedded in the final 
mortar in the painting. Texture type 2 is characterized by thin layers with similar chemical composition but with a clear interface between them, suggesting that the outer layer was set after the inner layer was already solidified. Additionally, the inner layer has coarser quartz grains than the outer layer. This texture is quite clear in the scanning electron microscopy images (SEM, Fig. 2).

Gypsum was the main addition used by Pennacchi. The presence of sulphur in the pictorial layer was detected in the SEM analyses. Pennacchi used gypsum with artistic purposes for producing local changes in texture, as observed in the smooth surfaces of texture type 2. It is worthwhile say that the presence of gypsum can be a source for efflorescence, but if the wall dressing is in a good condition, i.e., without cracks, efflorescence would not form. Pennacchi also used muscovite (mica) to improve brilliance, although it may reduce the adherence of the plaster on the wall dressing. Muscovite was also used by other mural painters, such as Carlos Magano in A marcha do conhecimento humano (The march of human knowledge) at the Education Faculty, University of São Paulo (Goulart 2001).

Pennacchi also used frames made of fibrous materials on which he set a tough mortar (Bardi 1980). In the literature, these fibres are known as celotex, which can be made of sugar-cane fibres or sawdust. Although Pennacchi clearly used fibres in his work, there is no previous information on the kind of fibre he used. Our data suggest that the fibres are from crushed sugar-cane, with a diameter ranging from 0.5 to $2 \mu \mathrm{m}$ (Fig. 3). Vegetable fibres or animal hair have been mixed in plasters since ancient times, as a way to increase resistance (Hodges 1964 apud Sickels 1982). Dasser (1991) points out that animal hair was used in mortars at the Seehof Castle, in Bamberg, Germany. Another characteristic of Pennacchi paintings is the presence of small bluish to violet dots, matching the colours at some portions of his frescoes.

\section{RESULTS}

The results presented in this section were obtained at the laboratories of the Institute of Geosciences of the University of São Paulo (IGc-USP). The plaster used by Pennacchi as base-layer for the mural paintings was made with a mixture of lime, sand, with or without fillers and pigments. It directly covers the bricks and is character- istic of the buon fresco technique. This corresponds to texture type 1 identified in the two analysed paintings. In texture type 2 there is a pigmented surface with additives forming a layer over the plaster.

\section{STEREOMICROSCOPY}

Collected samples were analysed under a Zeiss STEMi SV8 stereomicroscope, and photographed with a digital camera. Stereomicroscopical analysis revealed that the plaster contains aggregates of angular to very angular quartz grains, predominantly colourless, but also milky, orange or reddish, in a carbonatic matrix. The presence of minor amounts of muscovite and tourmaline were also detected. Tourmaline is an ubiquitous mineral in the alluvial sands of the Tietê and Pinheiro Rivers (Suguio and Takahashi 1970, K. Suguio et al., unpublished data), which may have been the source of aggregates for the frescoes base-layers. In general terms, the plaster is thin and cracked, with local occurrence of fissures and fractures and rounded voids or cavities. It was observed that the plaster contains fibres of different colours, such as colourless, black, blue and red.

The plaster in texture type 2 is very thin and not easily seen under the stereomicroscope.

Due to its deterioration, the Supper at Emmaus has some portions that are more porous and concentrate powdery efflorescences of soluble salts. Efflorescences and subefflorescences are found, the latter referring to salts deposited under the pictorial layer of the fresco (Fig. 4). The pictorial layer also contains very fine grains of opaque minerals or dark pigments disseminated throughout it.

\section{X-RAY DifFraCtion}

X-ray diffractometry was used to analyse the efflorescences, as well as to identify the plaster constitutive minerals. Samples of salts from the frescoes and walls were collected without damaging the paintings; in some cases tiny areas were sampled. Analyses were made in a Siemens D5000, with $\mathrm{CuK}_{\alpha}$ radiation, with angular velocity of $0.05^{\circ} / \mathrm{s}$.

Mineralogical analysis by X-ray diffractometry revealed the presence of quartz $\left(\mathrm{SiO}_{2}\right)$, calcite $\left(\mathrm{CaCO}_{3}\right)$, epsomite $\left(\mathrm{MgSO}_{4} \cdot 7 \mathrm{H}_{2} \mathrm{O}\right)$, microcline $\left(\mathrm{KAlSi}_{3} \mathrm{O}_{8}\right)$ and muscovite $\left(\mathrm{KAl}_{2}\left(\mathrm{AlSi}_{3} \mathrm{O}_{10}(\mathrm{OH})_{2}\right)\right.$ in the plaster. The 

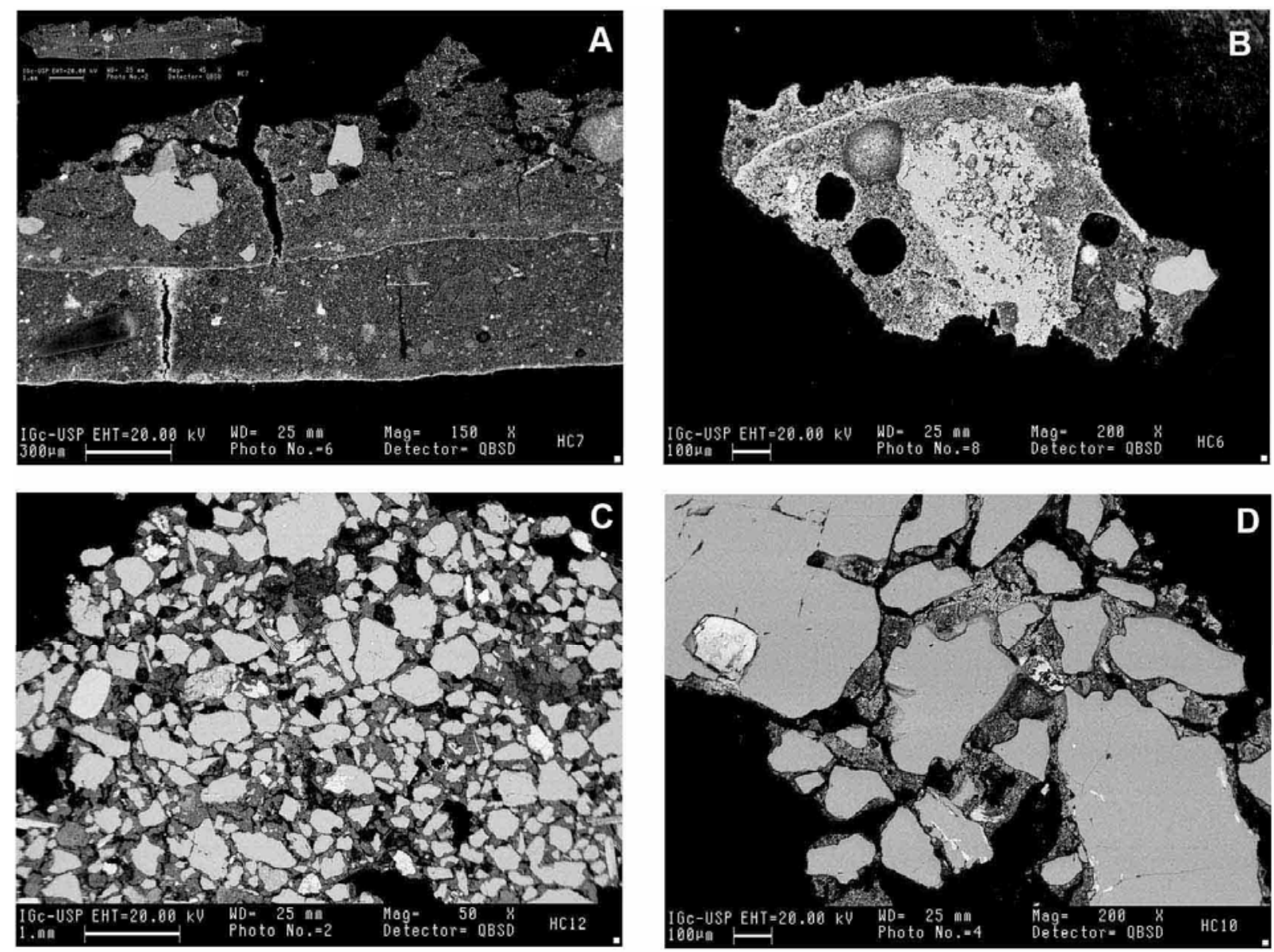

Fig. 2 - SEM images of distinct textures observed in the frescoes. A and B are texture type 2. C and D are texture type 1. Notice the very thin and continuous calcite layer in A and B.

absence of lime $(\mathrm{CaO})$ and portlandite $\left(\mathrm{Ca}(\mathrm{OH})_{2}\right)$ in the analyses indicate that any original lime in the plaster is by now thoroughly transformed into calcium carbonate.

In the efflorescence-bearing materials, quartz, calcite, gypsum $\left(\mathrm{CaSO}_{4} \cdot 2 \mathrm{H}_{2} \mathrm{O}\right)$, epsomite and muscovite were identified. In one single sample magnesite $\left(\mathrm{MgCO}_{3}\right)$ was found. Gypsum and epsomite were also identified in the walls of the Chapel, a little far away from the fresco.

\section{SCANNING ElECTRON Microscopy (SEM)}

Samples were analysed in a LEO 4401 scanning electron microscope, with a coupled Si-Li Oxford EDS detector (energy dispersive spectrometer). Operating conditions were $20 \mathrm{kV}$ voltage, 1 to $10 \mathrm{nA}$ current and 1 to $5 \mu \mathrm{m}$ beam diameter; in some cases, the conditions were $5.10^{-8} \mathrm{pm}$ and $0.5 \mu \mathrm{m}$ beam diameter.
Samples from well-preserved portions of the frescoes contain mainly calcite, quartz, magnesium carbonate, microcline, muscovite, gypsum and epsomite, together with minor amounts of biotite, kaolinite, ilmenite, monazite and zircon. In fragments or stratigraphic samples (cross-cut sections containing all the layers) a fairly compact plaster was observed, covered by a well crystallized cementitious carbonatic material, with pores and microfissures. Calcite predominates in interfaces between the layer of texture type 2 and the subjacent plaster. Fibres yield distinct compositions, being either carbon- or silicon-rich.

The pictorial layer (texture type 2) has pigments and additives and is quite irregular, varying in thickness from 200 to $700 \mu \mathrm{m}$. The pictorial layer and the subjacent plaster have similar compositions, with predominance of $\mathrm{Ca}$ and $\mathrm{Mg}$. 

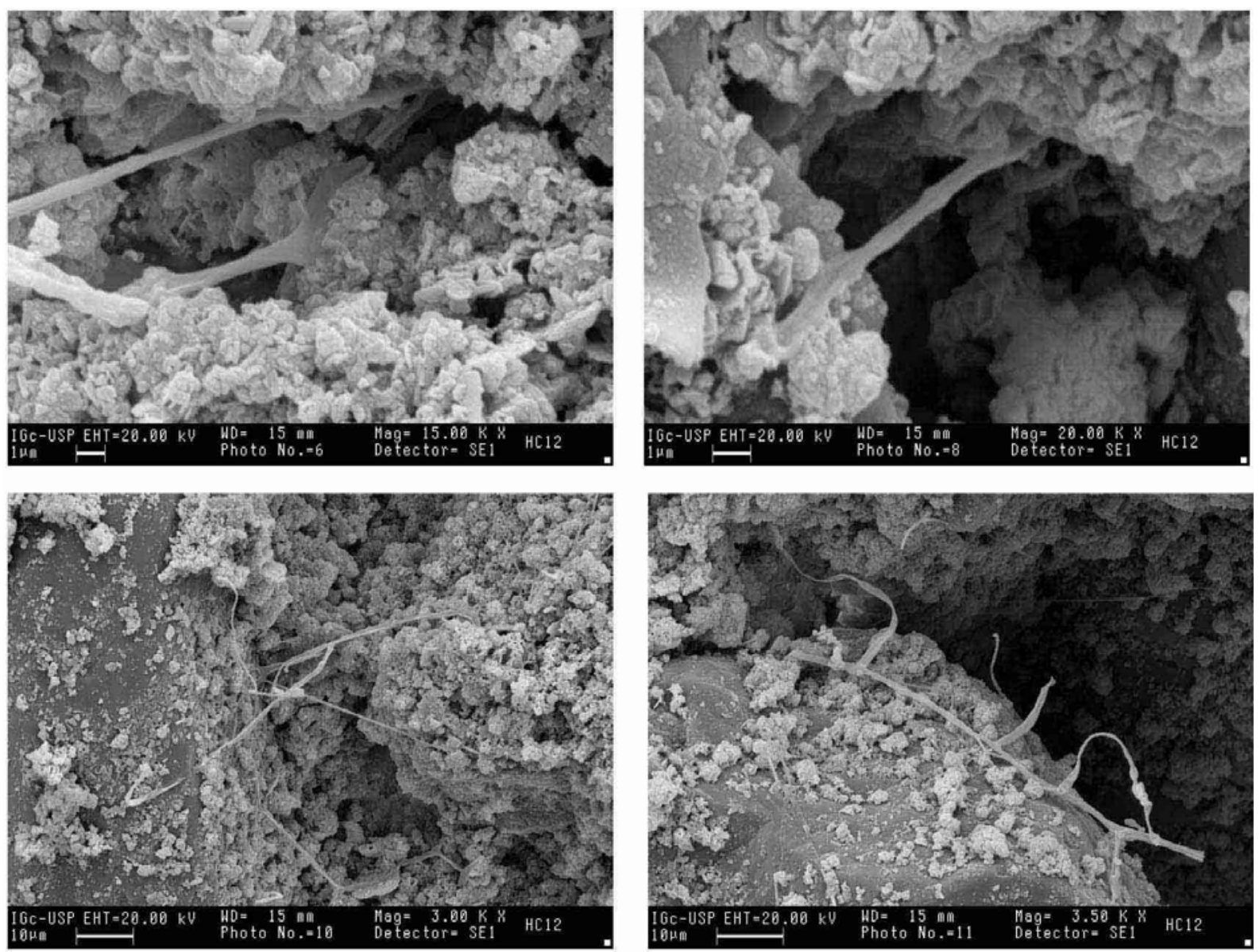

Fig. 3 -SEM images of fibrous materials used by Pennacchi to increase the mortar resistance.

The most abundant pigment is baryte $\left(\mathrm{BaSO}_{4}\right)$, followed by iron and lead in minor amounts. Other elements observed in connection to pigments were manganese, nickel, chromium, copper, titanium, silver and tin.

Analysis in efflorescence-bearing materials confirmed the presence of gypsum and epsomite.

ELECTRON Microprobe

Quantitative chemical microanalyses were made in a JEOL JXA-8600 SuperProbe electron microprobe using $15 \mathrm{kV}, 20 \mathrm{nA}$ and an electron beam diameter of $5 \mu \mathrm{m}$. These chemical microanalysis were made in stratigraphic sections. $\mathrm{CaO}$ and $\mathrm{MgO}$ contents are highly variable and display no clear tendency ( $\mathrm{CaO} 1.5$ to $37 \mathrm{wt} \%$; $\mathrm{MgO} 5$ to $32 \mathrm{wt} \%)$. Chemical data also indicate that $\mathrm{SO}_{3}$ distribution seems to be related to the texture of the fresco surface. In the true fresco (texture type 1 ), $\mathrm{SO}_{3}$ remains below $0.5 \mathrm{wt} \%$, while in the pigmented plaster with additives (texture type 2) it ranges between 0.9 and $2.6 \mathrm{wt} \%$, with an average close to $2.0 \mathrm{wt} \%$. In places with efflorescences, $\mathrm{SO}_{3}$ contents may reach up to $10.5 \mathrm{wt} \%$. Some oxides have been identified in the plaster with additives, probably related to the pigments, which are $\mathrm{FeO}(1.5$ to $3.8 \mathrm{wt} \%), \mathrm{BaO}(0.3$ to $1.4 \mathrm{wt} \%)$ and $\mathrm{TiO}_{2}$ (3.8 $\mathrm{wt} \%)$.

\section{Estimate of Aggregate/Binder Ratio AND \\ Chemical Composition of THE Mortar}

Chemical analyses and estimate of aggregate/binder ratio from the Chapel walls were made in the Construction Materials Laboratory (LMCC) of the Institute for Technological Researches (IPT, São Paulo). The results presented in Table I are from samples collected a little 

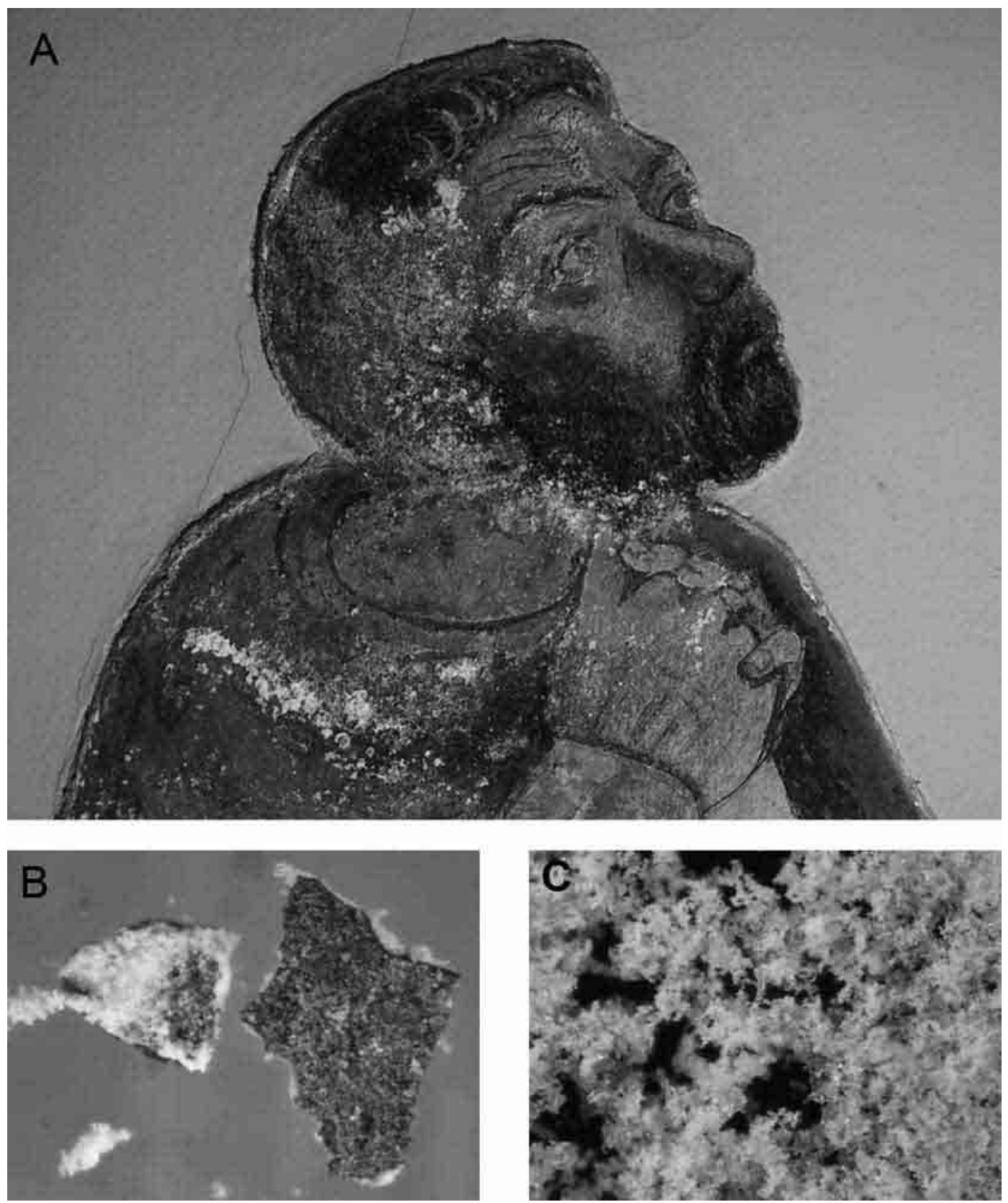

Fig. 4 - Detail of the fresco Supper at Emmaus with efflorescence features (A). Fragment of pictorial layer with subefflorescence (B), photo width $=3 \mathrm{~mm}$. Soluble salts seen under the stereomicroscope (C), photo width $=3 \mathrm{~mm}$.

far away from the frescoes. $\mathrm{SO}_{3}$ contents are fairly low in the mortar. This fact suggests that the sulphur of the efflorescences in the pictorial layer is not derived from the mortar.

\section{STATE OF CONSERVATION OF PENNACCHI'S WORKS AT HOSPITAL DAS CLÍNICAS}

The two frescoes in the Chapel of the Hospital das Clínicas display differences in their state of conservation. The Virgin Annunciation is relatively well preserved, with efflorescences in its upper part only. The other work, Supper at Emmaus, is more strongly damaged, revealing a disintegrated subjacent plaster, resulting in a loss of cohesion of the paint layer. Efflorescences are distinct in the two frescoes. At the Virgin Annunciation, efflorescence occurs on the surface of the pictorial layer. At the Supper at Emmaus it is concentrated mainly at the interface between the pictorial layer and the subjacent plaster, making the fresco to look powdery; this latter situation indicates a more advanced damage. 
TABLE I

Estimate of aggregate/binder ratio and chemical composition of the mortar in wt $\%$.

\begin{tabular}{c|c|c|c|c}
\hline \multirow{2}{*}{} & \multicolumn{2}{|c|}{ HC-38 } & \multicolumn{2}{c}{ HC-44 } \\
\cline { 2 - 5 } & original base & $\begin{array}{c}\text { non-volatile } \\
\text { base }\end{array}$ & original base & $\begin{array}{c}\text { non-volatile } \\
\text { base }\end{array}$ \\
\hline Humidity & 0.25 & - & 0.47 & - \\
\hline LOI & 6.35 & - & 7.94 & - \\
\hline Insoluble residue & 87.1 & 93.3 & 81.1 & 88.5 \\
\hline $\mathrm{SiO}_{2}$ & 0.24 & 0.26 & 0.56 & 0.61 \\
\hline Iron and aluminium & 0.53 & 0.57 & 0.94 & 1.03 \\
\hline oxides $\left(\mathrm{R}_{2} \mathrm{O}_{3}\right)$ & 5.66 & 6.06 & 6.73 & 7.35 \\
\hline $\mathrm{CaO}^{\mathrm{MgO}}$ & 0.23 & 0.25 & 2.51 & 2.74 \\
\hline $\mathrm{SO}_{3}$ & 0.01 & 0.01 & 0.01 & 0.01 \\
\hline $\mathrm{CO}_{2}$ & 4.05 & - & 2.71 & - \\
\hline Aggregate/binder ratio & \multicolumn{1}{|c|}{$13.9: 1$} & & $7.8: 1$ \\
\hline
\end{tabular}

Efflorescence is also present at the walls of the Chapel, not very far from the Virgin Annunciation. These soluble salts, particularly those with the anion $\left(\mathrm{SO}_{3}\right)^{2-}$, may have come from different sources (Del Lama et al. 2007):

(1) from the settled plaster that is directly in contact with the wall bricks;

(2) from the rendering layer that is the support to the pictorial layer;

(3) from the gypsum added to the pigments in the pictorial layer.

Chemical analyses of the mortars indicate fairly low $\mathrm{SO}_{3}$ contents, suggesting that the sulphur that forms efflorescences came from the pictorial layer itself. Epsomite $\left(\mathrm{MgSO}_{4} .7 \mathrm{H}_{2} \mathrm{O}\right)$ and gypsum $\left(\mathrm{CaSO}_{4} \cdot 2 \mathrm{H}_{2} \mathrm{O}\right)$ identified in relatively well preserved areas of the frescoes are the main constituents of the efflorescences, which, in turn, are spatially related to cracks in the Chapel walls. These cracks cross the walls and allow moisture to migrate from outside to inside the Chapel, as indicated by the damage signs in the outside dressing walls. Incoming water mobilizes sulphate ions from the pictorial layer that crystallize as efflorescences once water evaporates.

In the Supper at Emmaus another kind of damage was found mainly at the black and brown coloured areas, apparently caused by biological activity probably linked to previous restorations that used inappropriate materi- als (E.A. Del Lama et al., unpublished data). Due to the construction procedure, part of the fresco was painted on a false wall, i.e. an internal wall which is protected from the outside by an external wall, with a void between them. The fresco has no efflorescence in this place because it does not present any moisture, since it is isolated from the external wall as well as preserved against temperature oscillations (Fig. 5).

Some other meaningful features were also observed at and around the frescoes: i) traces of running water down the wall, mainly from a window at the left side of the Supper at Emmaus; ii) cracks in the pictorial layers, that have been sealed but are still recognizable with ultraviolet light; iii) droplets of pink colour at the Virgin Annunciation, from the wall painting.

A 1998 photography of the Virgin Annunciation does not show the efflorescences that are present today (CPC 2002), indicating that the accumulation of these soluble salts in remarkable amounts occurred in the last 8 years. In a general way, efflorescences at the Virgin Annunciation cause an aesthetic damage, while at the Supper at Emmaus they are causing more structural damages.

\section{CONCLUSIONS}

In the frescoes at the Hospital das Clínicas Chapel, it was recognized that Pennacchi not only used the buon fresco technique but also the mezzo fresco. The paint- 

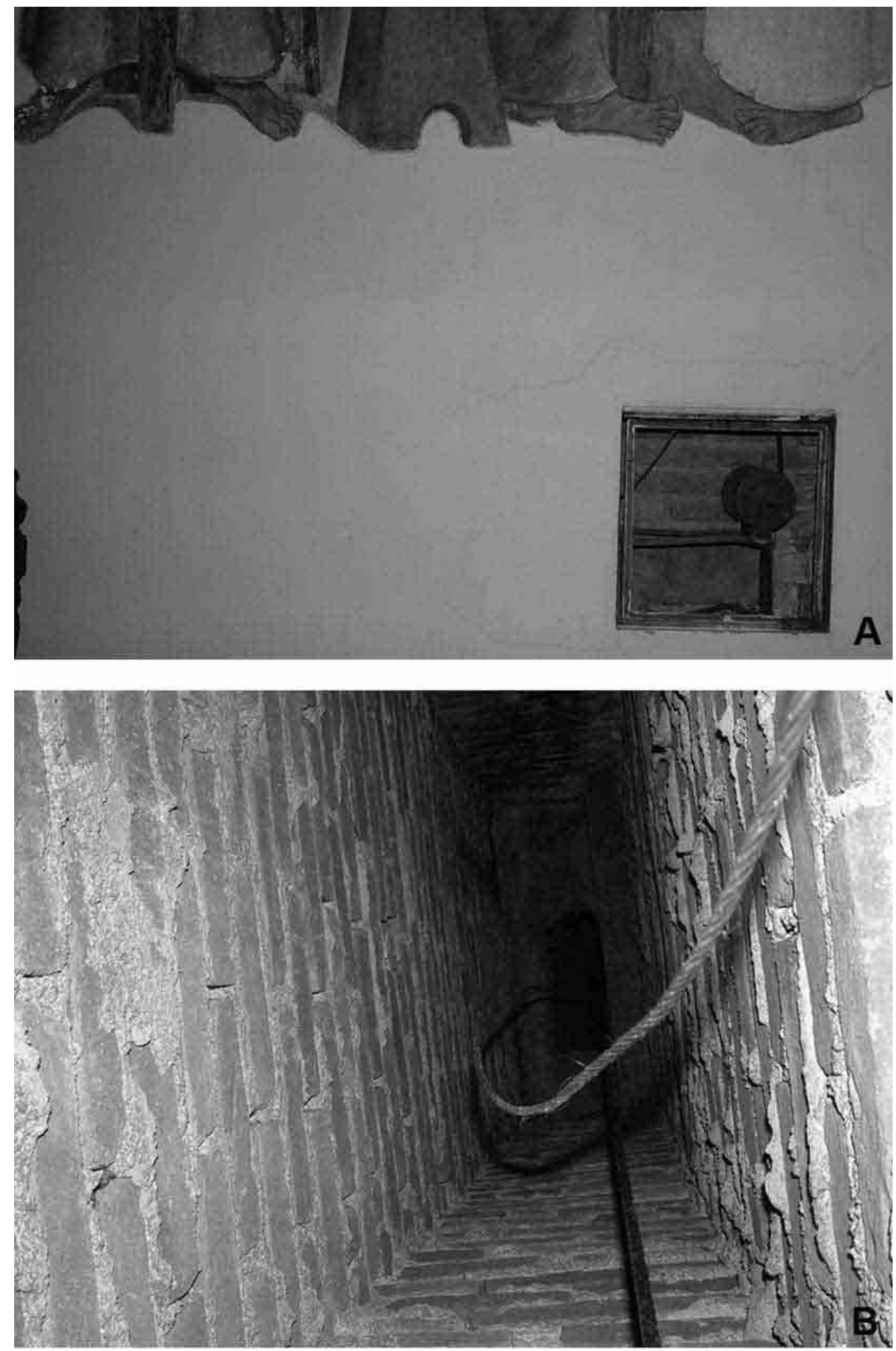

Fig. 5 - Bottom of fresco Supper at Emmaus and perpendicular view of false wall (A). False wall between the outer wall of the Chapel and the frescoed wall (B). 
ing was made on a rather compact plaster, with a well crystallized cementitious carbonatic material with fibres, and shows several microfissures. Porous areas turned powdery due to the presence of soluble salts occur. The actual plaster composition is calcite, dolomite, quartz, microcline and muscovite. The a priori hypothesis that Pennacchi used a single mixture in the plaster and obtained different textures by adding gypsum to a lime and sand mortar was corroborated. Gypsum addition may completely cover the underlying plaster, forming a fine texture layer.

With this procedure, two types of texture were produced: grainy plaster (texture type 1) and smooth plaster under the form of a fine layer (texture type 2). The pictorial layer with pigments and gypsum (texture type 2) contains mainly calcium carbonate, ranging between 200 and $700 \mu \mathrm{m}$ in thickness and shows an irregular topography. The lime of the mortar is completely carbonated, as indicated by the lack of $\mathrm{CaO}$ and $\mathrm{Ca}(\mathrm{OH})_{2}$ in the X-ray diffraction analysis. Fibres in the plaster are probably from crushed sugar-cane. The main additive used by Pennacchi was gypsum, in order to create different textures in some areas of his frescoes, as observed in texture type 2 that shows smooth surfaces. Barite $\left(\mathrm{BaSO}_{4}\right)$ is the main pigment, followed by iron and lead, in minor amounts.

The state of conservation of the two frescoes is distinct, with the Virgin Annunciation showing some efflorescences in its uppermost portion only, while the Supper at Emmaus has deeper damage forms, with subefflorescences, locally losing its pictorial layer and revealing the underlying plaster. The efflorescences on the Virgin Annunciation aesthetically damage the painting, while the damage forms occurring in Supper at Emmaus are threatening the paintings integrity.

\section{ACKNOWLEDGMENTS}

This work presents results of the research project Mineralogical techniques applied to the study of mural paintings by Fulvio Pennacchi: A case study. The authors are thankful to the Fundação de Amparo à Pesquisa do Estado de São Paulo (FAPESP) for the financial support (process 05/51310-3).

\section{RESUMO}

A presente pesquisa trata de duas pinturas murais feitas em 1947 por Fulvio Pennacchi com a técnica do afresco na Capela Católica do Hospital das Clínicas (São Paulo, Brasil), intituladas Anunciação da Virgem e Ceia de Emaús. Este estudo considera os materiais e as técnicas de pintura usadas pelo artista, baseado na pesquisa histórica, observações in situ e técnicas analíticas de laboratório (estereomicroscopia, microscopia eletrônica de varredura com detector de espectro de energia dispersiva, difração de raios X, microssonda eletrônica, imagens obtidas com luz ultravioleta), visando aperfeiçoar os métodos de caracterização de objetos do nosso patrimônio cultural, e otimizar sua preservação adequadamente. Os resultados conduziram à identificação dos componentes da argamassa e as diferentes camadas nos afrescos, além de informações sobre a granulação, impurezas e texturas, composição dos pigmentos, e feições de deterioração, tal como eflorescência. O grau de degradação das pinturas murais foi avaliado desta maneira. Nossos dados sugerem que Pennacchi usou uma camada única de argamassa com agregados de granulação fina a média. Diferenças na textura foram obtidas pela adição de gesso à argamassa.

Palavras-chave: eflorescência, afresco, análises mineralógicas, Pennacchi, Capela do Hospital das Clínicas.

\section{REFERENCES}

Bardi PM. 1980. Fulvio Pennacchi. São Paulo: Raízes, $185 \mathrm{p}$.

CPC (Comissão de Patrimônio Cultural). 2002. Bens imóveis tombados ou em processo de tombamento da USP. São Paulo: Edusp/Imprensa Oficial do Estado de São Paulo, 224 p.

DASSER KL. 1991. Pre-treatment examination and documentation: the wall paintings of $\operatorname{Schlo} \beta$ Seehof, Bamberg. In: CATHER S (Ed), The Conservation of wall paintings, London. Proceedings of a Symposium organized by the Courtauld Institute of Art and the Getty Conservation Institute in 1987, Los Angeles: The Getty Conservation Institute, p. 21-27.

Del Lama EA, Andrade FRD, Kihara Y and Tirello RA. 2007. Estudo de eflorescências em pinturas murais de Fulvio Pennacchi. ARC (Revista Brasileira Arqueometria Restauração Conservação) 1: 92-95.

GOUlart EP. 2001. Caracterização microestrutural e microquímica da argamassa e dos pigmentos. In: TIRELLO 
RA (Org), O restauro de um mural moderno na USP: o afresco de Carlos Magano, São Paulo: CPC-PRCEU-USP, p. $154-163$.

Lourenço MCF. 1995. Operários da Modernidade. São Paulo: Hucitec/EDUSP, 322 p.

Manzano E, Bueno AG, Gonzalez-Casado A And OLMO M. 2000. Mortars, pigments and binding media of wall paintings in the 'Carrera del Darro' in Granada, Spain. J Cult Heritage 1: 19-28.

MAYER R. 1982. Artist's handbook of materials and techniques. New York: Viking, $731 \mathrm{p}$.

Mora P, Mora L AND Philippot P. 1984. Conservation of Wall Paintings. London, Boston: Butterworths, 494 p.

PAVÍA S AND CARO S. 2006. Lime mortars for masonry repair: analitical science and laboratory testing versus practical experience. In: DELGADo RodRIGUES J AND Mimoso J (Eds), Theory and Practice Conservation? A Tribute to Cesari Brandi, Lisbon. Proceedings of the International Seminar, Lisbon: LNEC, p. $493-500$.

PennacChi VA. 2002. Pennacchi - Pintura Mural. São Paulo: Metalivros, $131 \mathrm{p}$.
Pinacoteca do Estado de São Paulo. 2006. Pennacchi 100 anos. São Paulo: Pinacoteca, 164 p.

SICKELS LB. 1982. Organics vs. synthetics: their use as additives in mortars. In: MORTARS, CEMENTS AND Grouts USED IN THE CONSERVATION OF HistoriC Buildings, Rome. Symposium, 1981, Rome: ICCROM, p. 25-52.

Suguio K AND TAKahashi LI. 1970. Estudo dos aluviões antigos dos Rios Pinheiros e Tietê, São Paulo, SP. An Acad Bras Cienc 42: 555-570.

TIRELLO RA. 2001. O restauro de um mural moderno na USP: o afresco de Carlos Magano. São Paulo: CPC-PRCEUUSP, $204 \mathrm{p}$.

TiRello RA AND Del LAma EA. 2006. La pintura al fresco moderna brasileña: studios de caracterización material y ejecución de los murales de Fulvio Pennacchi (São Paulo/Brasil). In: Pifferetti AA And Bolmaro RE (Eds), Metodologías científicas aplicadas al estudio de los bienes culturales: datación, caracterización, prospección, comunicación, Rosario: Humanidades y Artes Ediciones - H. y A., p. 201-207. 